\title{
Measuring the dimensions of adaptive capacity: a psychometric approach
}

\author{
Michael Lockwood $^{1}$, Christopher M. Raymond $^{1,2,3}, \underline{\text { Eddie Oczkowski }}^{4}$ and Mark Morrison $^{5}$
}

\begin{abstract}
Although previous studies have examined adaptive capacity using a range of self-assessment procedures, no objective self-report approaches have been used to identify the dimensions of adaptive capacity and their relative importance. We examine the content, structure, and relative importance of dimensions of adaptive capacity as perceived by rural landholders in an agricultural landscape in South-Eastern Australia. Our findings indicate that the most important dimensions influencing perceived landholder adaptive capacity are related to their management style, particularly their change orientation. Other important dimensions are individual financial capacity, labor availability, and the capacity of communities and local networks to support landholders' management practices. Trust and confidence in government with respect to native vegetation management was not found to be a significant dimension of perceived adaptive capacity. The scale items presented, particularly those with high factor loadings, provide a solid foundation for assessment of adaptive capacity in other study areas, as well as exploration of relationships between the individual dimensions of adaptive capacity and dependent variables such as perceived resilience. Further work is needed to refine the scale items and compare the findings from this case study with those from other contexts and population samples.
\end{abstract}

Key Words: adaptive capacity; psychometric scales; rural landholders; structural equation modelling

\section{INTRODUCTION}

Research into adaptive capacity has attempted to understand interactions between social and biophysical systems, with the goal of developing mechanisms to support responses to global environmental change (Folke et al. 2002, Adger 2003a, Nelson et al. 2010a), and to maximize the success of conservation actions with limited resources (Sexton et al. 2010). Adaptive capacity is a latent property of an individual, community, or socialecological system, which is activated in response to a crisis or opportunity (Engle 2011). High adaptive capacity imparts resilience to an individual, community, or social-ecological system so that they are more likely to be able to maintain a desired state, or negotiate a favorable transformation when the current state is untenable or undesirable (Folke 2006). From a sociocultural perspective, Gupta et al. (2010:461) defined adaptive capacity as the "characteristics of institutions that empower social actors to respond to short and long-term impacts either through planned measures or through allowing and encouraging creative responses from society both ex ante and ex post." Our concern is with the formal measurement of adaptive capacity as perceived by a population sample of individuals for whom such capacity is critical for their future environment and livelihoods.

Assessments of adaptive capacity have used a range of techniques including inductive theory driven approaches (Pelling et al. 2008, Gupta et al. 2010); assessment of secondary data sources (Adger and Vincent 2005, Brooks et al. 2005, Adger 2006, Smit and Wandel 2006, Eriksen and Kelly 2007); self-assessment processes (Brown et al. 2010, Raymond and Cleary 2013); and futures modelling (Bussey et al. 2012).

A number of studies have identified indicators of adaptive capacity, often collating and sorting indicators from the vulnerability and resilience literatures. Indicators have been aggregated stepwise into indices (Schröter et al. 2005, Cabell and Oelofse 2012, Schneiderbauer et al. 2013) or sorted into dimensions (Yohe and Tol 2002, Schröter et al. 2005, Gupta et al. 2010). These dimensions are subsequently typically measured using secondary data sources. In Australia, for example, researchers have analyzed the overall adaptive capacity of rural communities to global change using the rural livelihoods framework (Ellis 2000), which includes an assessment of social, human, built, and natural capital using data provided by the Australian Bureau of Statistics (Nelson et al. 2005, 2007, 2010a). The strength of this approach is that it enables the development of nationally consistent and standardized measures of adaptive capacity. However, these sustainable livelihood assessments have been criticized because of their failure to consider important contextual information (Park et al. 2012), as well as providing little opportunity for local stakeholders to shape the assessment (Brown et al. 2010).

In response to the issues associated with national assessments, recent studies have focused on the development of approaches that enable local actors and resource managers at the local scale to self-assess their capacity to respond to environmental changes using deductive approaches. Brown et al. (2010) developed a tool that enabled local communities to self-assess capacity using the rural livelihoods 5-capitals framework as a guide. The tool was focused on the assessment of the capacity of local resource users to manage environmental change. Park et al. (2012) developed a workshop process that enabled local experts to assess variables related to human, social, natural, physical, and financial capital. Consensus was reached through facilitated discussions and negotiations between group members. Raymond and Cleary (2013) also developed a tool and process for negotiating the strength of indicators related to the 5-capitals; additionally, participants were asked to assess the level and importance of capacity at institutional, organizational, and individual tiers of government, and their level of confidence in their assessment. Although these tools enable higher levels of stakeholder engagement in the assessment of adaptive capacity, as well as the

${ }^{1}$ Geography and Spatial Sciences, School of Land and Food, University of Tasmania, ${ }^{2}$ Centre for Regulation and Market Analysis and Barbara Hardy Institute, University of South Australia, ${ }^{3}$ Enviroconnect, ${ }^{4}$ School of Accounting and Finance, Charles Sturt University, ${ }^{5}$ School of Management and Marketing, Charles Sturt University 
Table 1. Dimensions of adaptive capacity identified in the literature.

\begin{tabular}{|c|c|c|}
\hline Dimension & & Supporting sources \\
\hline Social capital & $\begin{array}{l}\text { Local networks } \\
\text { Trust } \\
\text { Reciprocity }\end{array}$ & $\begin{array}{l}\text { IPCC (2001), Pretty and Ward (2001), Adger (2003a), Adger and Vincent } \\
\text { (2005), Armitage (2005), Folke et al. (2005), Pelling and High (2005), Pahl- } \\
\text { Wostl (2009) }\end{array}$ \\
\hline $\begin{array}{l}\text { Human, financial, } \\
\text { and physical capital }\end{array}$ & $\begin{array}{l}\text { Knowledge and information } \\
\text { Labor and time } \\
\text { Finance and infrastructure }\end{array}$ & $\begin{array}{l}\text { Ellis (2000), Smith et al. (2000), IPCC (2001), Yohe and Tol (2002), Brooks et } \\
\text { al. (2005), Engle and Lemos (2010), Gupta et al. (2010), Nelson et al. (2010a, } \\
\text { b), Morrison et al. (2011) }\end{array}$ \\
\hline $\begin{array}{l}\text { Management } \\
\text { approach }\end{array}$ & $\begin{array}{l}\text { Innovation } \\
\text { Adaptive management } \\
\text { Risk behavior }\end{array}$ & $\begin{array}{l}\text { IPCC (2001), Ivey et al. (2004), Allan and Curtis (2005), Folke et al. (2005), } \\
\text { Grothmann and Patt (2005), Tompkins and Adger (2005), Walker et al. } \\
\text { (2006), Engle and Lemos (2010) }\end{array}$ \\
\hline Governance & $\begin{array}{l}\text { Legitimacy } \\
\text { Accountability } \\
\text { Inclusion and fairness } \\
\text { Leadership } \\
\text { Coordination and collaboration }\end{array}$ & $\begin{array}{l}\text { Adger (2003b), Ivey et al. (2004), Brooks et al. (2005), Folke et al. (2005), } \\
\text { Olsson et al. (2006), Nelson et al. (2007), Pahl-Wostl et al. (2007), Vincent } \\
\text { (2007), Folke et al. (2009), Engle and Lemos (2010), Gupta et al. (2010), } \\
\text { Engle (2011), Holman and Trawick (2011), Plummer (2013), Plummer et al. } \\
\text { (2013) }\end{array}$ \\
\hline
\end{tabular}

potential for building capacity through the process, the statistical validity and reliability of the measures are unknown.

We are not aware of studies that have used psychometrics to both statistically identify dimensions of adaptive capacity and test their construct validity. One possible reason is that adaptive capacity has been largely developed within the vulnerability and resilience literatures (Engle 2011) and is largely absent from the psychology literature. Psychometrics is concerned with the study of differences between individuals, involves the construction of instruments and procedures for measurement, and the development and refinement of theoretical approaches to measurement (Michell 1999). The potential contribution of a psychometric approach to the study of adaptive capacity is in the identification of constructs, which are statistically robust dimensions of adaptive capacity for a particular sample population, and the relative importance of these dimensions. In the context of a psychometric survey conducted on a sample population, a construct is "the abstract idea, underlying theme, or subject matter that one wishes to measure" (Lavrakas 2008).

As a latent construct, adaptive capacity is not amenable to direct measurement. Our approach was to first identify the dimensions of adaptive capacity, which the literature suggests might be of significance, and then develop question items to empirically measure these dimensions. Given our psychometric approach, we consider a sample population's perceptions of both individual dimensions, such as financial capacity, and collective dimensions, such as governance and social capital. We developed psychometric scales for these dimensions and tested their internal consistency (reliability) and validity (how well the construct is defined by the measures) using factor analysis (see Russell 2002, Hair et al. 2006).

Our primary objective, using a psychometric approach, was to identify constructs, which are valid and reliable dimensions of adaptive capacity for a sample of landholders within an Australian agricultural landscape. Note that our psychometric approach sought to understand how individuals perceive their capacity in relation to dimensions, which theory and the literature suggest are important attributes of adaptive capacity. This contrasts with indicator-based approaches, which use secondary data sources. Our Australian case study was the Tasmanian
Midlands, an agricultural region, which includes nationally significant biodiversity features. Key drivers influencing these biodiversity features include irrigation developments, enterprise profitability, climate change, and invasive processes (Mitchell et al. 2013). The perceived adaptive capacity of landholders to respond to these drivers will be critical in determining future social, economic, and environmental outcomes in the region.

\section{DIMENSIONS OF ADAPTIVE CAPACITY}

As summarized in Table 1, the dimensions of landholder adaptive capacity were derived from a review of the literature. We elaborate on each dimension.

\section{Social capital}

Social capital broadly refers to a set of networks, agreements, and flows of information (Adger et al. 2005). "It incorporates features of social organization such as trust, norms and networks that can improve the efficiency of society by facilitating coordinated actions" (Putnam et al. 1993:167). Social capital is a lens for examining how social networks and social norms, including reciprocity, contribute to adaptive capacity (Pelling and High 2005), particularly in coping with risk and environmental change (Adger 2003a, Adger and Vincent 2005). Social capital facilitates collaboration and cooperation between local and nonlocal actors in times of stress and the effective delivery of management efforts to cope with threats to resources and resource users (Adger 2003a, Armitage 2005). Social capital can also be used to generate material interventions directed at reducing vulnerability to climate change or background stressors, as well as to generate institutional modifications to address both climate stress and background stress (Pelling and High 2005). The three aspects of social capital most likely to influence adaptive capacity are trust, reciprocity, and networks.

Although there is general recognition that trust is important in adaptive capacity (Folke et al. 2005), the way in which it influences the construct remains unclear (Adger and Vincent 2005). The strongest evidence comes from the adaptive comanagement literature, which highlights that strategies for building collaboration and trust assists in the management of risks and conflict in complex multilevel systems (Armitage et al. 2009). In the natural resource management literature, studies have also 
distinguished between the trust that develops among individuals and between individuals and groups (Berry et al. 2011, Morrison et al. 2011, Sharp et al. 2012).

Trust can create a social obligation, engaging reciprocal action, which is referred to as reciprocity (Pretty and Ward 2001). Providing space for individuals to develop private as well as publicly sanctioned social relationships is seen as an important resource for adaptation. Pelling et al. (2008) showed how such relationships contribute to the accumulation of trust and reciprocity between stakeholders, assisting in the formation of planned adaptations to environmental change. Theorists have drawn a distinction between specific forms of reciprocity and diffuse reciprocity (Keohane 1986). Specific reciprocity refers to the ability to exchange items of roughly equal value with others, whereas in diffuse reciprocity people help each other without expecting an immediate service or reward. We build upon Pretty and Ward's (2001) measures of trust, which examined the extent to which landholders are willing to exchange items of approximately equal value with their neighbors or to help their neighbors out without expecting any immediate reward or benefit.

Informal and formal networks have an important role in social learning processes for managing environmental change and are a major structural characteristic of governance regimes (PahlWost1 2009), as well as informal group dynamics (Pretty and Ward 2001). Networks can be structured horizontally or vertically. Horizontal networks bring together people of the same status and power, and vertical networks join individuals who are different in terms of hierarchy or dependence. Pretty and Ward (2001) referred to horizontal networks in terms of: (1) local connections, i.e., connections between individuals within groups; (2) local-local connections, i.e., connections between groups and communities; (3) local-external connections, i.e., connections between local groups and external agencies; and (4) external-external connections, i.e., connections between external agencies, which lead to collaborative partnerships. For example, Raymond and Robinson (2013) found that adaptation can be influenced by the social networks among governance agencies, communities of practice, e.g. farm system groups, as well as trusted advisors, e.g., farm consultants, who are able to translate complex environmental change concepts into locally relevant advice.

\section{Human, financial, and physical capital}

Human, financial, and physical resources have been found to be paramount to the ability to manage societal vulnerability to climate change and to undertake effective adaptation actions (Yohe et al. 1996, Smith et al. 2000, Yohe and Tol 2002, Nelson et al. 2010a). Recent studies have included indicators of human, financial, and physical resources in adaptive capacity and vulnerability assessment frameworks (Brown et al. 2010, Gupta et al. 2010, Nelson et al. 2010a).

Indicators of human, financial, and physical capital are largely based on the sustainable rural livelihoods framework (Ellis 2000). Human resources refer to the availability of skills, expertise, knowledge, and human labor (Gupta et al. 2010, Nelson et al. $2010 a$ ), as well as good health and physical capability to undertake livelihood activities (Ellis 2000). Financial resources refer to the financial capital available to support policy measures and financial incentives (Gupta et al. 2010). Physical resources refer to capital created by economic production processes, such as roads, machinery, and tools (Ellis 2000).

Researchers have measured financial resources in terms of the level of off-farm investment, off-farm employment, and/or the availability of cash to undertake natural resource management (NRM) (Cary et al. 2001, Emtage et al. 2001, Brown et al. 2010), in addition to the level of incentive support (Moon and Cocklin 2011). Studies have considered human resources in relation to the level of enthusiasm and optimism for NRM, good health and nutrition, willingness to change or innovate, and willingness to seek new information (Brown et al. 2010, Morrison et al. 2011, Park et al. 2012); and contrastingly, the amount of labor and time available to undertake NRM practices (Morrison et al. 2011, Morrison and Lockwood 2014). Physical resources have been assessed in terms of the amount of conservation farming equipment or low input farming, paddock size (Pannell et al. 2006, Brown et al. 2010), communications, and water resource infrastructure (Park et al. 2012).

\section{Landholder management approach}

Models of individual adaptive capacity "ought to include sociocognitive variables," because the motivation to adapt is driven by goals, values, and norms, including perceptions of risk and personal estimates of adaptation ability (Grothmann and Patt 2005:209). In the context of our case study, landholders' adaptive capacity can be supported or constrained by their approach to managing their properties. Key dimensions for adaption include risk behavior, attitudes to innovation, as well as willingness to embrace an adaptive management approach (Tompkins and Adger 2005, Engle and Lemos 2010).

The learning approach to management, adaptive management, is predicated on the fact that social-ecological systems are managed with incomplete knowledge and that there is an imperative to monitor management outcomes and adjust management strategies, activities, and practices based on the results of the assessment (Walker et al. 2006). Experimentation, innovation, and learning are the defining values of active adaptivity (Allan and Curtis 2005). Such learning is supported by individuals' willingness to learn through iterative decision making that constantly assesses outcomes from interventions and revises strategies accordingly (Tompkins and Adger 2005).

\section{Governance}

Institutional arrangements affect individuals' and communities' capacity to adapt (Ivey et al. 2004, Engle 2011). In the context of collective action for natural resource management and biodiversity conservation, governance institutions provide the mechanisms by which adaptive capacity is realized (Adger 2003b). Actors engaged at all scales and levels of governance develop and implement adaptation policies, foster adaptive capacity, and undertake adaptive actions (Plummer 2013). Rigidly hierarchical, poorly coordinated, or ill-informed governance can also be a barrier to adaptation (Engle and Lemos 2010). Adaptive capacity demands that a governing body is intentional in its management of change and is able to rearrange internal processes and procedures in response to changing internal or external conditions (Gunderson et al. 1995). There is empirical support for governance as a contributing dimension of adaptive capacity. Brooks et al. (2005) tested three determinants of adaptive capacity, i.e., education, health, and governance, and found 
governance to be the most important. Engle and Lemos (2010) found a positive relationship between integrated water governance and adaptive capacity in 18 Brazilian river basins.

Institutional conditions supportive of adaptive capacity include widely accepted attributes of good governance (Nelson et al. 2007, Vincent 2007, Kumler and Lemos 2008, Engle and Lemos 2010). Specifications of good governance have been offered in the form of principles with international reach (UNDP 1997, Kaufmann et al. 2003), requirements for effective common-property governance (Ostrom 1990), and context-specific treatments of sustainability (MSRM 2004) and protected areas (Graham et al. 2003, Lockwood 2010). Common dimensions in these specifications are legitimacy, accountability, inclusion, fairness, leadership, and coordination. Gupta et al. (2010) used legitimacy (public support for an institution), equity (fair rules), responsiveness to society, and accountability as indicators of fair governance for adaptive capacity.

Armitage (2005) and Plummer et al. (2013) argued that for governance to support adaptive capacity, outcomes need to be transparently accounted for by those with responsibilities for their implementation. This is supported by the findings of Brooks et al. (2005), who found accountability and government responsiveness to citizen concerns to be important governance indicators of positive climate change adaption. Ivey et al. (2004) identified the extent of public participation in decision making and implementation as a dimension of adaptive capacity. Participation can build trust and shared understanding, which in turn can mobilize coordinated action and encourage the emergence of self-organized governance structures (Lebel et al. 2006).

Leadership for adaptive capacity is visionary, entrepreneurial, and collaborative (Gupta et al. 2010). Leadership has a major role in adaptive capacity for building trust, developing and communicating visions, managing conflict, linking different actors, societal levels, and knowledge systems, initiating partnerships, compiling and generating knowledge, and mobilizing support for change (Armitage 2005, Pahl-Wostl et al. 2007, Engle and Lemos 2010, Gupta et al. 2010, Plummer et al. 2013). Leaders must also be able to generate and make the most of windows of opportunity when change becomes necessary (Folke et al. 2005).

Holman and Trawick (2011) found that horizontal integration across sectoral policies and practices, and vertical integration across the governance scales were important contributors to adaptive capacity. Governance connectivity is important in building shared recognition of interdependencies among issues and in allowing actors to address shared problems in a concerted fashion. Linking different actors in networks to create opportunities for novel interactions is critical for learning and fostering integrated adaptive responses to change (Folke et al. 2009).

\section{METHODS}

\section{Choice of study area}

For our purposes, the Tasmanian Midlands study area was delineated by 15 Australian Bureau of Statistics statistical area level 1 divisions (SA1s), which are the smallest units for which census data are publicly released. The selected SA1s cover one of the oldest agricultural regions in Australia, with stock grazing dating back to the 1820 s. Over $95 \%$ of the land is under private ownership, with most of this a mosaic of cleared agricultural lands and remnant native forests, woodlands, and grasslands. In 2011, the Tasmanian Midlands total population was 4709, which was less than $1 \%$ of Tasmania's population of 489,029 . There are several rural towns in the region, the largest being Campbell Town, with a population of approximately 800 (Gadsby et al. 2013).

Grazing of sheep for wool and meat, and cattle for meat, are the largest enterprises in the region, with recent diversification into crops such as peas, cereals, potatoes, and poppies. Expanded irrigation schemes will likely lead to an extension of irrigated agriculture in the near future. The land-use history of the region has resulted in a number of conservation issues, including fragmentation of remnant vegetation, rural tree decline, and degradation of native grassland (Mooney et al. 2010). The Tasmanian Midlands region has been identified as one of 15 national biodiversity hotspots by the Australian government. In particular, lowland native grasslands are the most depleted vegetation formation in Tasmania and are listed as critically endangered under the Environment Protection and Biodiversity Conservation Act 1999 (Cth).

A social-ecological systems analysis (Mitchell et al. 2013) demonstrated that the region's landholders face significant challenges including: (1) maintaining the economic viability of their agricultural enterprises in the face of declining terms of trade for their traditional grazing enterprises; (2) maintaining the currently well-developed social capital of a traditional farming community given the potential for corporate agribusiness to become significant landowners through taking advantage of water allocations from a recently developed irrigation scheme; (3) responding to expected climatic changes, which will affect the relative viability of different enterprise types; and (4) continued pressures to conserve nationally significant biodiversity features, which constrain agricultural development options. Landholders with well-developed adaptive capacity are likely to be best placed to meet these challenges.

\section{Survey population and instrument}

Data were collected using a mail survey of rural landholders in the Tasmanian Midlands. The survey population comprised Midland's landholders who owned properties larger than two hectares. The two-hectare threshold ensured that urban residents were excluded, consistent with our purpose of examining the perceived adaptive capacity of rural landholders.

The initial database of 688 rural-Midlands landholders was found to include a number of incorrect addresses and individual landholders with multiple addresses. After accounting for these undeliverable surveys, a response rate of $44 \%$ was achieved, comprising 266 returned surveys. A small number of returns (16) contained a significant proportion of incomplete responses, which would prove problematic for data analysis, and consequently, surveys that contained more than $50 \%$ of missing data for the employed variables were omitted from the analysis. This exclusion resulted in a usable sample of 250 responses, which contained $7.7 \%$ missing observations. 
To test the representativeness of our results, we first took a subsample of respondents, who self-identified as farmers or farm managers as their main occupation, i.e., $38.6 \%$ of all respondents. Overall, there is a bias to more formally educated and female farmer respondents. The proportion of male farmer respondents was identical to Australian Bureau of Statistics (ABS) regional data, i.e., $41.5 \%$ in each case; however, double the proportion of female farmers/farm managers responded, i.e., $28.5 \%$ survey vs. $14.3 \%$ ABS region (ABS 2012). The majority of respondents $(63.2 \%)$ and self-identified farmers $(65.6 \%)$ had a postschool education, including trade, diploma, or tertiary education, compared with $45.7 \%$ of people who identified themselves as farmers/farm managers in regional census data (ABS 2012), suggesting a slight bias toward more formally educated respondents. The average area of farm businesses in the Tasmanian Midlands survey was 1635.4 ha, which is similar to regional statistics of 1750.4 ha (Gadsby et al. 2013).

The key survey questions comprised a series of multi-item scales designed to measure the dimensions of adaptive capacity summarized in Table 1. For each dimension, we devised multiple items to test which of these were the most reliable measures of the construct. To test the face validity, i.e., whether the scale items could be understood by survey participants, a pretest of the scale items was conducted with two focus groups of rural landholders and land management officials. Each item was measured on five point Likert scales. In total, 85 potential scale items were included in the final survey, representing the 14 dimensions of adaptive capacity in Table 1.

Additionally, based on previous literature and the focus group discussion, we included four scale items to represent perceived individual resilience to environmental change. This construct was included to act as a dependent variable, which enabled estimation of a structural equation model. We postulated that the empirically derived dimensions of adaptive capacity would be significant predictors of resilience to environmental change. To examine the representativeness of the sample, information on sociodemographics such as age, gender, main occupation, level of formal education, equity in business, and employment type was also obtained in the survey.

\section{Data analyses}

First, we used Cronbach alpha, a coefficient of internal consistency, to test the reliability of the item sets as measures of each dimension of adaptive capacity. Items with low intercorrelations were excluded from further analysis, so that each dimension was measured using those items that maximized Cronbach alpha. In the same way, the internal consistency of the items measuring perceived individual resilience was also assessed.

Second, factor analysis enabled us to empirically identify the dimensions, or factors, underlying these measures. Once these dimensions were identified, we created scores to represent the factors, which could be used in subsequent analyses of our data. Third, we assessed the construct validity of the dimensions of adaptive capacity using a confirmatory modelling strategy. We employed confirmatory factor analysis (CFA) to define the underlying structure among the variables in the measurement model. The size of the factor loadings generated by CFA is one important consideration in testing construct validity. High loadings on a factor would indicate that the scale items converge on common points, which in our analysis were the dimensions of adaptive capacity.

Fourth, as a check of construct validity, we assessed whether our dimension measures are correlated with another construct in a way that meets theoretical expectations (Goodwin 2010). We selected perceived individual resilience as a suitable construct for this test because the literature identifies that resilience is closely associated with adaptive capacity (Folke et al. 2010). In this test, the dimensions of adaptive capacity were used as independent variables to explain variations in perceived resilience in an appropriately constructed structural equation model.

Another way of testing construct validity is to determine the average variance extracted (AVE) among a set of construct items. An AVE of 0.5 or higher is a good rule of thumb for adequate convergence, indicating that more of the construct is explained by the items than is unexplained. Discriminant validity can be tested in CFA by comparing the variance-extracted percentages for any two constructs with the square of the correlation estimate between these two constructs. The assumption is that a latent construct should explain its item measures more effectively than it explains another construct. Confirmatory factor analysis also enables the testing of the internal consistency of the measurement model. Two commonly applied reliability tests are composite reliability (Peterson and Kim 2013) and Cronbach alpha (Cronbach 1951). Tests with high stability coefficients tend to have high internal consistency. Nunnally and Bernstein (1994) recommended a value of 0.70 as acceptable and 0.90 as excellent, whereas Moss et al. (1998:178) stated that 0.60 is generally considered to be acceptable.

A variety of software packages exist for CFA modelling. We used the full information maximum likelihood procedure (FIML) for estimating models with missing observations available in STATA version 13.0. The FIML represents a model-based approach for missing data treatment, which produces relatively unbiased and efficient results (Enders and Bandalos 2001). Given the structure of the model and underpinning assumptions, the estimates for the parameters are derived without the need to impute data for missing observations. Following Anderson and Gerbing (1988) and current practice, a two-step approach was employed: first, the measurement model was refined using CFA; second, the complete structural equation model (SEM) was estimated. A single measurement model for all the multi-item constructs was initially analyzed, which allowed all constructs to covary. A number of initially hypothesized items were omitted in the refinement process because of poor CFA goodness of fit measures, low reliabilities, and/or low AVE values.

\section{RESULTS}

\section{Reliability of dimension subscales}

Item sets for each of the dimensions indicated in Table 1 were tested for their reliability using Cronbach alpha. Because the survey contained less than three items for legitimacy, accountability, inclusion, and fairness, the five components of governance were assessed collectively. After removing items with poor intercorrelations, the item sets that constituted reliable measures of each dimension are indicated in Table 2. This procedure resulted in the pool of items on "trust" being reduced to only those items concerning landholders' perceptions of 
Table 2. Reliability of adaptive capacity subscales.

\begin{tabular}{lll}
\hline \hline Dimension & Cronbach alpha & Items \\
\hline Local networks & 0.801 & $\begin{array}{l}\text { As a result of building connections with local groups I am better able to achieve my nature conservation goals. } \\
\text { As a result of building connections with local groups I better understand how my conservation management } \\
\text { contributes to the Tasmanian and Australians communities. } \\
\text { As a result of building connections with local groups I better understand the social, economic, and } \\
\text { environmental factors affecting my property. } \\
\text { As a result of building connections with local groups I have more trust in people from government agencies. }\end{array}$ \\
$\begin{array}{ll}\text { Trust in } \\
\text { government }\end{array}$ & 0.640 & a
\end{tabular}

government

For management of native vegetation in the Midlands, I believe you can trust government organizations to do what is right most of the time.

For management of native vegetation in the Midlands, I believe it's a mistake to get involved with government programs because they always change. ${ }^{\dagger}$

Reciprocity $\quad 0.736 \quad$ I feel a responsibility to make a contribution to the community I live in.

If there was a serious problem in this community, people would get together and solve it.

People around here are generally supportive of each other.

Information $\quad 0.812 \quad$ During the last five years did you use farm industry newsletters or brochures, and how useful was that

behavior information?

During the last five years did you use a private agronomist/consultant, and how useful was that information?*

Labor and time $\quad 0.721$

I have enough labour to manage native vegetation.

I find it difficult to find the time to complete the property management tasks I already have to do. ${ }^{\dagger}$

I have enough time to manage native vegetation.

Finance and $\quad 0.685$

I have sufficient financial resources to manage native vegetation.

infrastructure

I like to try new things, but finding the cash to enable them to be done can be difficult. ${ }^{\dagger}$

Financially, I cannot afford to make a poor decision, even a small one. ${ }^{\dagger}$

I have the equipment/infrastructure needed to manage native vegetation.

Innovation $\quad 0.772 \quad$ I am open to new ideas and alternatives about farm or other land management.

I am willing to try new things.

Knowing about new technology and methods is important to me.

Adaptive

I have clear and measurable management goals.

management

I monitor and evaluate progress against my management goals.

It is important to me that I learn from my successes and failures.

Risk behavior $\quad 0.483 \quad$ Financially, I can afford to take a few risks and experiment with new ideas.

I am able to manage environmental risks.

I am able to manage economic risks.

Governance $\quad 0.872 \quad$ For management of native vegetation in the Midlands, I believe government agencies are responsive to local community needs and concerns.

For management of native vegetation in the Midlands, I believe government environment programs are fair for all Midlands landholders.

For management of native vegetation in the Midlands, I believe I have opportunities to have my say about government environmental programs and decisions.

For management of native vegetation in the Midlands, I believe government agencies provide good leadership.

For management of native vegetation in the Midlands, I believe there is good coordination between

government agencies, nongovernment organizations, and local groups.

For management of native vegetation in the Midlands, I believe government agencies, nongovernment organizations, and local groups have a common vision.

${ }^{5}$ Measured on a scale $1=$ never used, $2=$ little used, $3=$ useful, $4=$ very useful. All other items measured on a scale $1=$ strongly disagree, $2=$ disagree, $3=$ neither agree nor disagree, $4=$ agree, $5=$ strongly agree.

${ }^{\dagger}$ Reverse coded.

government, with removal of items concerning trust of local and nongovernment conservation organizations. The scales for local networks, trust in government, reciprocity, information behavior, labor and time, finance and infrastructure, innovation, adaptive management, and governance have acceptable reliabilities, i.e., above 0.60 . However, the item set was not reliable for risk behavior.

\section{Confirmatory factor analysis (CFA) of the dimensions of adaptive capacity}

We used CFA to test the construct validity of the dimensions of adaptive capacity presented in Table 2 . First, we attempted to develop a factor model for perceived adaptive capacity based on the dimensions as outlined in the theoretical framework (Table 1). Although the dimensions of social capital, human, financial and physical capital, landholder management approach, and governance were identified as appropriate factors in isolation, together they did not load with high construct validity on an overarching construct of adaptive capacity. For subsequent analyses, we therefore examined the dimensions listed in Table 2 as separate factors, rather than deriving an overall measure of perceived adaptive capacity. The use of the individual dimensions of adaptive capacity to explain perceived individual resilience 
Table 3. Dimensions of adaptive capacity and personal resilience: validity and reliability.

\begin{tabular}{|c|c|c|c|c|c|c|}
\hline Scale item & $\lambda$ & $\mathrm{t}$ & $\begin{array}{l}\text { Grand } \\
\text { mean }\end{array}$ & $\begin{array}{l}\text { Item } \\
\text { mean }\end{array}$ & S.D. & $\begin{array}{l}\text { Cronbach } \\
\text { alpha }\end{array}$ \\
\hline Local networks & & & 3.26 & & 0.71 & 0.80 \\
\hline $\begin{array}{l}\text { As a result of building connections with local groups I better understand } \\
\text { how my conservation management contributes to the Tasmanian and } \\
\text { Australians communities. }\end{array}$ & 0.812 & 16.35 & & 3.21 & 0.76 & \\
\hline $\begin{array}{l}\text { As a result of building connections with local groups I better understand } \\
\text { the social, economic, and environmental factors affecting my property. }\end{array}$ & 0.822 & 18.48 & & 3.37 & 0.78 & \\
\hline $\begin{array}{l}\text { As a result of building connections with local groups I am better able to } \\
\text { achieve my nature conservation goals. }\end{array}$ & 0.646 & 9.38 & & 3.22 & 0.69 & \\
\hline Trust in government & & & 2.55 & & 0.81 & 0.66 \\
\hline $\begin{array}{l}\text { As a result of building connections with local groups I have more trust in } \\
\text { people from government agencies. }\end{array}$ & 0.622 & 4.64 & & 2.67 & 0.76 & \\
\hline $\begin{array}{l}\text { For management of native vegetation in the Midlands, I believe you can } \\
\text { trust government organizations to do what is right most of the time. }\end{array}$ & 0.794 & 5.46 & & 2.43 & 0.93 & \\
\hline Reciprocity & & & 3.89 & & 0.61 & 0.73 \\
\hline I feel a responsibility to make a contribution to the community I live in. & 0.711 & 10.76 & & 3.85 & 0.81 & \\
\hline $\begin{array}{l}\text { If there was a serious problem in this community, people would get together } \\
\text { and solve it. }\end{array}$ & 0.809 & 12.56 & & 4.04 & 0.72 & \\
\hline People around here are generally supportive of each other. & 0.596 & 8.70 & & 3.80 & 0.61 & \\
\hline Human, financial, and physical capital & & & 2.82 & & 0.87 & 0.85 \\
\hline I have sufficient financial resources to manage native vegetation. & 0.737 & 13.73 & & 2.88 & 0.96 & \\
\hline I have the equipment/infrastructure needed to manage native vegetation. & 0.548 & 8.31 & & 2.94 & 0.9 & \\
\hline I have enough labor to manage native vegetation. & 0.875 & 18.77 & & 2.75 & 1.02 & \\
\hline I have enough time to manage native vegetation. & 0.871 & 28.68 & & 2.77 & 0.93 & \\
\hline Innovation & & & 3.99 & & 0.64 & 0.77 \\
\hline $\begin{array}{l}\text { I am open to new ideas and alternatives about farm or other land } \\
\text { management. }\end{array}$ & 0.726 & 13.88 & & 4.04 & 0.79 & \\
\hline I am willing to try new things. & 0.616 & 9.50 & & 4.07 & 0.64 & \\
\hline Knowing about new technology and methods is important to me. & 0.845 & 17.80 & & 3.83 & 0.83 & \\
\hline Adaptive management & & & 3.71 & & 0.64 & 0.77 \\
\hline I have clear and measurable management goals. & 0.838 & 18.24 & & 3.58 & 0.77 & \\
\hline I monitor and evaluate progress against my management goals. & 0.844 & 21.49 & & 3.4 & 0.80 & \\
\hline It is important to me that I learn from my successes and failures. & 0.535 & 9.06 & & 4.16 & 0.69 & \\
\hline Information behavior & & & 2.18 & & 0.91 & 0.81 \\
\hline $\begin{array}{l}\text { During the last five years did you use farm industry newsletters or } \\
\text { brochures, and how useful was that information? }\end{array}$ & 0.664 & 15.65 & & 2.48 & 0.93 & \\
\hline $\begin{array}{l}\text { During the last five years did you use a private agronomist/consultant, and } \\
\text { how useful was that information? }\end{array}$ & 0.844 & 23.07 & & 2.19 & 1.17 & \\
\hline $\begin{array}{l}\text { During the last five years did you use farm industry advisory staff, and how } \\
\text { useful was that information? }\end{array}$ & 0.813 & 19.45 & & 1.91 & 0.95 & \\
\hline Personal resilience & & & 3.77 & & 0.59 & 0.66 \\
\hline I am still able to manage my property well during the tough times. & 0.712 & 10.77 & & 3.76 & 0.68 & \\
\hline In times of change I am good at adapting and facing up to challenges. & 0.696 & 9.36 & & 3.80 & 0.67 & \\
\hline
\end{tabular}

Note: All measures employ a 1-5 scale, where $1=$ strongly disagree and $5=$ strongly agree, except for information behavior, which employs a $1-4$ scale, with $1=$ never used and $4=$ very useful.

allows for the identification of their relative strengths and therefore potentially provides richer results than deriving a single overall measure.

We used structural equal modeling to test the path relationships between the dimensions in Table 2, apart from risk behavior, which had a low reliability, and perceived individual resilience, as measured by two survey items: "I am still able to manage my property well during the tough times" and "In times of change I am good at adapting and facing up to challenges." Governance consistently had very low coefficients and significance. Labor and time, and finance and infrastructure performed best when four of the scale items were combined into a measure of human, financial, and physical capital, which is consistent with the classification given in Table 1. Trust in government performed best if one of the items was removed from this subscale. Following these adjustments, seven of the nine dimensions from Table 2 had loadings that are statistically significant at the $1 \%$ level, providing evidence of convergent validity. The estimated factor loadings, tratios, summary statistics, and Cronbach alphas are given in Table 3. The model has acceptable fit statistics: $x^{2}$ /df (chi-square/ degrees of freedom $)=1.86$, CFI $($ comparative fit index $)=0.913$, and RMSEA (root mean square error of approximation) $=0.059$.

Table 4 provides the construct correlations, AVEs, and composite reliability estimates. All the composite reliability estimates and Cronbach alphas exceed 0.65 , and only the reliabilities for the constructs of trust and 'perceived individual resilience' fall slightly 
Table 4. Construct correlations and reliabilities.

\begin{tabular}{|c|c|c|c|c|c|c|c|c|}
\hline & (1) & (2) & (3) & (4) & (5) & (6) & (7) & (8) \\
\hline (1) Adaptive management & 1.0 & & & & & & & \\
\hline (2) Innovation & 0.496 & 1.0 & & & & & & \\
\hline (3) Information behavior & 0.390 & 0.556 & 1.0 & & & & & \\
\hline (4) Trust in government & 0.103 & 0.036 & 0.266 & 1.0 & & & & \\
\hline (5) Local networks & -0.029 & 0.142 & 0.156 & 0.442 & 1.0 & & & \\
\hline (6) Reciprocity & 0.158 & 0.219 & 0.294 & 0.321 & 0.297 & 1.0 & & \\
\hline (7) Human, financial, and physical capital & 0.248 & 0.027 & -0.085 & 0.059 & 0.157 & 0.127 & 1.0 & \\
\hline (8) Personal resilience & 0.485 & 0.488 & 0.222 & 0.067 & 0.251 & 0.335 & 0.384 & 1.0 \\
\hline Average variance extracted & 0.567 & 0.540 & 0.604 & 0.509 & 0.584 & 0.505 & 0.592 & 0.496 \\
\hline Composite reliability & 0.791 & 0.776 & 0.820 & 0.671 & 0.806 & 0.751 & 0.849 & 0.663 \\
\hline
\end{tabular}

below 0.70 . These results point to good reliability properties for the employed measures. The majority of the factor loadings exceed 0.60 and all are statistically significant at the $1 \%$ level. To assess convergent validity, we note that all AVEs approximately equal or exceed 0.50 ; this implies that more variation in the data is explained rather than being a consequence of measurement error (Fornell and Larcker 1981). To examine discriminant validity, we note that the AVEs of all the constructs exceed their respective squared correlations with other constructs. This suggests that measures explain more of their own variation rather than that shared with other constructs (Fornell and Larcker 1981). In other words, even given the presence of measurement error, the measures are demonstrably different from each other.

As expected, all the pair-wise construct correlations with perceived individual resilience are positive (Table 4), which implies explanatory power for the hypothesized independent variables. The majority of correlations between the independent variables are relatively low, implying that a high degree of multicollinearity is not likely to be problematic. In summary, the measures possess good reliability and validity properties.

\section{Relationships between dimensions of adaptive capacity and perceived individual resilience}

After using CFA to refine the measurement model (Tables 3, 4), we then estimated the relationships between dimensions of adaptive capacity as independent variables, and perceived individual resilience as a dependent variable. The standardized direct path estimates, and their t-ratios based both on FIML standard errors and robust standard errors, are presented in Table 5. The robust standard errors are employed to detect any substantial influence on the FIML standard errors of possible departures in distributional assumptions. In general, the robust standard errors produce slightly lower t-ratios than their FIML counterparts. However, in all cases the level of statistical significance of variables remains unaffected.

The results support the hypotheses that perceived individual resilience is practically and statistically significantly dependent, at the $5 \%$ level, upon innovation (standardized $\beta=0.340$ ), adaptive management $(\beta=0.283)$, human, financial, and physical capital $(\beta=0.248)$, and reciprocity $(\beta=0.198)$. Local networks $(\beta=0.175)$ has a relatively large standardized coefficient but is marginally statistically insignificant at the $10 \%$ level. Information behavior ( $\beta=-0.116)$ and trust in government $(\beta=-0.099)$ do not have a significant statistical impact on perceived individual resilience.
Table 5. Personal resilience and adaptive capacity: standardized path estimates.

\begin{tabular}{lccc}
\hline \hline $\begin{array}{l}\text { Personal } \\
\text { resilience }\end{array}$ & $\begin{array}{c}\text { Path } \\
\text { estimates }\end{array}$ & Personal resilience & $\begin{array}{c}\text { Path } \\
\text { estimates }\end{array}$ \\
\hline Adaptive & 0.283 & Local networks & 0.175 \\
management & $(2.75)^{\dagger}$ & & $(1.62)$ \\
& {$[2.26]^{\dagger}$} & & {$[1.51]$} \\
Innovation & 0.340 & Reciprocity & 0.198 \\
& $(2.85)^{\dagger}$ & & $(2.21)^{\dagger}$ \\
& {$[2.09]^{\dagger}$} & & {$[1.97]^{\dagger}$} \\
Information & -0.116 & Human, financial, and & 0.248 \\
behavior & $(-1.03)$ & physical capital & $(2.96)^{\dagger}$ \\
& {$[-1.00]$} & & {$[2.89]^{\dagger}$} \\
Trust in & -0.099 & & \\
government & $(-0.79)$ & & \\
& {$[-0.66]$} & & \\
\hline 5\% significance ML t-ratios in ( ), robust t-ratios in [ ]. & \\
\hline
\end{tabular}

\section{DISCUSSION}

Although a range of self-assessment procedures has been used to evaluate adaptive capacity, as far as we are aware no psychometric self-report approaches have previously been used to identify the dimensions of perceived adaptive capacity and their relative importance. Consequently, our objective was to test the construct validity and reliability of a series of scales designed to measure the dimensions of adaptive capacity previously identified in the literature and their relative importance in influencing perceived adaptive capacity. Our analytical methods also provide a foundation for future adaptive capacity inquiries seeking to improve the measurement of individual dimensions of adaptive capacity. For example, our empirical results reveal particular scale items, e.g., "as a result of building connections with local groups I have more trust in people from government agencies," which require revision.

Our results indicate that the most important constructs influencing perceived adaptive capacity are related to landholders' orientation toward change. The highest loadings in the structural equation model were for innovation and adaptive management. Thus, those landholders that currently embrace change as business as usual have the highest adaptive capacity. These landholders are best able to manage in the tough times, adapt to, and face challenges. Their innovation, access to capital, and adaptive approach to land management mean that 
landholders with well-developed perceived adaptive capacity are more likely to identify and adopt financially attractive alternatives to traditional grazing enterprises, including taking advantage of water allocations from a recently developed irrigation scheme and undertaking enterprise planning, which takes into account expected medium and long terms changes in local climatic conditions. Such innovation would help them stay on the land, providing a buffer against increasing corporate agribusiness ownership in the Midlands, and in association with their strong local networks, help to maintain the well-developed social capital in the region.

The remaining significant explanatory variables are human, financial, and physical capital, and reciprocity. These variables reflect landholders' individual capacity to cope with difficulty and the need to change, and the capacity of communities to support individuals during these periods. Higher levels of human, financial, and physical capital mean that individual landholders have greater resources and capacity to make necessary changes and manage for long periods with limited income, such as during drought. Higher levels of reciprocity mean that landholders have strong communities that work together to support each other through periods of adversity. The significance of reciprocity is unsurprising given the range of studies showing the importance of this and related constructs (Pretty and Ward 2001, Armitage 2005, Folke et al. 2005, Pelling and High 2005). Previous work using secondary data has found empirical links between adaptive capacity and human and financial capital as well as adaptive management (Nelson et al. 2007). We add to this literature by demonstrating that change management is also important.

The insignificant variables in the structural equation model were trust in government, with respect to native vegetation management, and information behavior. To these can be added the governance construct, which was not included in the reported structural equation model because of its low significance and relative unimportance. This construct effectively represents confidence in institutional environmental management. The insignificance of these variables contrasts with findings in related studies, such as those identifying the predictors of past participation in agro-environmental programs, in which trust in government and information usage have been found to be significant predictors (Morrison et al. 2011, Morrison and Lockwood 2013). The insignificance of these variables also contrasts with literature that posits the importance of landholder responses to institutional settings as a dimension of adaptive capacity (Ivey et al. 2004). It is unclear why these variables are insignificant in this context, and further research may serve to clarify the reasons for this finding.

Using psychometrics, we were able to identify seven dimensions of capacity with moderate-high internal validity, i.e., local networks; trust in government; reciprocity; human, financial, and physical capital; innovation; adaptive management; and information behavior. These scales will be useful for researchers seeking to measure individual dimensions of capacity in other study areas and for comparing the relationships between individual dimensions and dependent variables such as perceived individual resilience or proenvironmental behavior. However, we were unable to confirm that the seven dimensions of capacity formed part of a first order construct of adaptive capacity, and therefore, cannot conclude that we have generated a single adaptive capacity scale. The low coherence can be attributed to the low factor loading scores $(<0.70)$ for many of the scale items and low reliability (Cronbach alpha $<0.75$ ) for many of the capacity dimensions. Our resilience measure had low internal validity (factor scores $<0.75$ ) and reliability (Cronbach alphas < 0.70 ); hence there is scope to improve the measure of perceived individual resilience. Adding new or alternative items may increase the internal validity and reliability of each dimension and of our resilience measure.

We also encourage researchers to consider the face validity of all new items generated, i.e., whether the item can be easily understood by the land manager and whether that land manager can distinguish between it and other items theorized to be related to that dimension of capacity. The scale items presented, particularly those with high factor loading scores, provide a solid foundation for future exploratory work.

Further, the self-reported and context specific nature of our data means that (1) the results are conditioned by the degree of selfawareness of respondents, and (2) not necessarily generalizable to other populations or study areas. In particular, the finding that some dimensions were unimportant is specific to our sample population and case study context, and may not be replicated in other study areas. What is generalizable is our approach and the potential for other researchers to draw on and further refine our item subscales. The external validity of a modified scale can be tested by applying it in multiple study areas, ideally with different biophysical or social contexts.

Another limitation of this study is the sample size. A census of the population was conducted, and unfortunately the number of landholders in the region prohibited obtaining a larger sample. The sample bias toward more educated, female respondents also means that we cannot conclude that the results are fully representative of the Midlands farming population. Males had significantly stronger information-seeking behavior than females ( $t=2.59, p=0.01)$, suggesting that our biased sample may have resulted in an underestimation of the effect of information behavior on overall adaptive capacity and perceived individual resilience. However, any underestimation of information behavior is likely to have been moderated by the slight education bias. More formally educated respondents had significantly higher levels of self-reported human, financial, and physical capital, innovation, adaptive management, and information behavior $(F>2.15, p<$ $0.05)$.

Lastly, there is a need to repeat this approach in other geographic and land-use contexts, in which population and land management differences may lead to changes in the relative importance of the dimensions of perceived adaptive capacity. The results presented here reflect responses from rural landholders who, in the main, are in a later stage of their life cycle (female mean age $=55$ years; male mean age $=57$ years). It is possible that the structure and content of adaptive capacity may be different in peri-urban or regional areas containing a greater diversity of age groupings, lifestyles, and farming goals. It would therefore be prudent to further develop the psychometric scale presented here in both rural and peri-urban contexts, with the ultimate goal of assessing the external validity or generalizability of the seven dimensions of capacity. Research questions such as which dimensions are 
salient to all contexts, and which dimensions are pertinent to only rural or peri-urban contexts could be considered as part of such analyses.

\section{CONCLUSION}

This is the first study of which we are aware that has examined adaptive capacity using a psychometric self-report approach to identify the dimensions of adaptive capacity and their relative importance. The scale items presented, particularly those with high factor loadings, provide a solid foundation for assessment of adaptive capacity in other study areas, as well as exploration of relationships between the individual dimensions of adaptive capacity and dependent variables such as perceived individual resilience. Our findings indicate that the most important constructs influencing perceived landholder adaptive capacity in our study area are related to landholders' change orientation. Those landholders for whom change is business as usual are likely to have a higher level of perceived adaptive capacity. Other important dimensions of adaptive capacity are related to individual capacity in terms of financial and labor resources, the capacity of communities to support individual landholders, especially during times of hardship, and the ability of local networks to help landholders improve their conservation practices and management. Insignificant variables were trust and confidence in government with respect to native vegetation management, and information-seeking behavior. Further work is needed to refine our scale items and compare the findings from this case study with those from other contexts and population samples.

Responses to this article can be read online at: http://www.ecologyandsociety.org/issues/responses. $\mathrm{php} / 7203$

\section{Acknowledgments:}

This work is an output from the Landscapes and Policy Research $H u b$. The hub is supported through funding from the Australian Government's National Environmental Research Program. We thank the focus group and survey participants for their participation and responses.

\section{LITERATURE CITED}

Australian Bureau of Statistics (ABS). 2012. National regional profile 2007-2011. Australian Bureau of Statistics, Canberra, Australia.

Adger, W. N. 2003a. Social capital, collective action, and adaptation to climate change. Economic Geography 79:387-404.

Adger, W. N. 2003b. Social aspects of adaptive capacity. Pages 29-49 in J. B. Smith, R. J. T. Klein, and S. Huq, editors. Climate change, adaptive capacity and development. Imperial College Press, London, UK.

Adger, W. N. 2006. Vulnerability. Global Environmental Change 16:268-281. http://dx.doi.org/10.1016/j.gloenvcha.2006.02.006
Adger, W. N., and K. Vincent. 2005. Uncertainty in adaptive capacity. Comptes Rendus Geoscience 337:399-410. http://dx.doi. org/10.1016/j.crte.2004.11.004

Adger, W. N., N. W. Arnell, and E. L. Tompkins. 2005. Successful adaptation to climate change across scales. Global Environmental Change 15:77-86. http://dx.doi.org/10.1016/j.gloenvcha.2004.12.005

Allan, C., and A. Curtis. 2005. Nipped in the bud: why regional scale adaptive management is not blooming. Environmental Management 36(3):414-425. http://dx.doi.org/10.1007/s00267-004-0244-1

Anderson, J. C., and D. W. Gerbing. 1988. Structural equation modeling in practice: a review and recommended two-step approach. Psychological Bulletin 103(3):411-423. http://dx.doi. org/10.1037//0033-2909.103.3.411

Armitage, D. 2005. Adaptive capacity and community-based natural resource management. Environmental Management 35 (6):703-715. http://dx.doi.org/10.1007/s00267-004-0076-Z

Armitage, D. R., R. Plummer, F. Berkes, R. L. Arthur, A. T. Charles, I. J. Davidson-Hunt, A. P. Diduck, N. C. Doubleday, D. S. Johnson, M. Marschke, P. McConney, E. W. Pinkerton, and E. K. Wollenberg. 2009. Adaptive co-management for socialecological complexity. Frontiers in Ecology and the Environment 7(2):95-102. http://dx.doi.org/10.1890/070089

Berry, H. L., A. Hogan, S. P. Ng, and A. Parkinson. 2011. Farmer health and adaptive capacity in the face of climate change and variability. Part 1: health as a contributor to adaptive capacity and as an outcome from pressures coping with climate related adversities. International Journal of Environmental Research and Public Health 8:4039-4054. http://dx.doi.org/10.3390/ijerph8104039

Brooks, N., W. N. Adger, and P. M. Kelly. 2005. The determinants of vulnerability and adaptive capacity at the national level and the implications for adaptation. Global Environmental Change 15:151-163. http://dx.doi.org/10.1016/j.gloenvcha.2004.12.006

Brown, P. R., R. Nelson, B. Jacobs, P. Kokic, J. Tracey, M. Ahmed, and P. DeVoil. 2010. Enabling natural resource managers to selfassess their adaptive capacity. Agricultural Systems 103:562-568. http://dx.doi.org/10.1016/j.agsy.2010.06.004

Bussey, M., R. W. Carter, N. Keys, J. Carter, R. Mangoyana, J. Matthews, D. Nash, J. Oliver, R. Richards, A. Roiko, M. Sano, D. C. Thomsen, E. Weber, and T. F. Smith. 2012. Framing adaptive capacity through a history-futures lens: lessons from the South East Queensland Climate Adaptation Research Initiative. Futures 44:385-397. http://dx.doi.org/10.1016/j.futures.2011.12.002

Cabell, J. F., and M. Oelofse. 2012. An indicator framework for assessing agroecosystem resilience. Ecology and Society 17(1): 18. http://dx.doi.org/10.5751/ES-04666-170118

Cary, J., N. Barr, H. Aslin, T. Webb, and S. Kelson. 2001. Human and social aspects of capacity to change to sustainable management practices. Bureau of Rural Sciences, Canberra, Australia.

Cronbach, L. J. 1951. Coefficient alpha and the internal consistency of tests. Psychometrika 16:297-334. http://dx.doi. org/10.1007/BF02310555

Ellis, F. 2000. Rural livelihoods and diversity in developing countries. Oxford University Press, Oxford, UK. 
Emtage, N. F., S. R. Harrison, and J. L. Herbohn. 2001. Landholder attitudes to and participation in farm forestry activities in sub-tropical and tropical eastern Australia. Pages 195-210 in S. R. Harrison and J. L. Herbohn, editors. Sustainable farm forestry in the tropics. Edward Elgar, Cheltenham, UK.

Enders, C. K., and D. L. Bandalos. 2001. The relative performance of full information maximum likelihood estimation for missing data in structural equation models. Structural Equation Modeling 8(3):430-457. http://dx.doi.org/10.1207/S15328007SEM0803 5

Engle, N. L. 2011. Adaptive capacity and its assessment. Global Environmental Change 21:647-656. http://dx.doi.org/10.1016/j. gloenvcha.2011.01.019

Engle, N. L., and M. C. Lemos. 2010. Unpacking governance: building adaptive capacity to climate change of river basins in Brazil. Global Environmental Change 20:4-13. http://dx.doi. org/10.1016/j.gloenvcha.2009.07.001

Eriksen, S. H., and P. M. Kelly. 2007. Developing credible vulnerability indicators for climate adaptation policy assessment. Mitigation and Adaptation Strategies for Global Change 12:495-524. http://dx.doi.org/10.1007/s11027-006-3460-6

Folke, C. 2006. Resilience: the emergence of a perspective for social-ecological systems analyses. Global Environmental Change 16:253-267. http://dx.doi.org/10.1016/j.gloenvcha.2006.04.002

Folke, C., S. Carpenter, T. Elmqvist, L. Gunderson, C. S. Holling, and B. Walker. 2002. Resilience and sustainable development: building adaptive capacity in a world of transformations. Ambio 31:437-440.

Folke, C., S. R. Carpenter, B. Walker, M. Scheffer, T. Chapin, and J. Rockström. 2010. Resilience thinking: integrating resilience, adaptability and transformability. Ecology and Society 15(4): 20. [online] URL: http://www.ecologyandsociety.org/vol15/iss4/ $\underline{\operatorname{art} 20 /}$

Folke, C., F. S. Chapin, III, and P. Olsson. 2009. Transformations in ecosystem stewardship. Pages 103-125 in F. S. Chapin, III, G. P. Kofinas, and C. Folke, editors. Principles of ecosystem stewardship: resilience-based natural resource management in a changing world. Springer, New York, New York, USA. http://dx. doi.org/10.1007/978-0-387-73033-2_5

Folke, C., T. Hahn, P. Olsson, and J. Norberg. 2005. Adaptive governance of social-ecological systems. Annual Review of Environment and Resources 30:441-473. http://dx.doi.org/10.1146/ annurev.energy.30.050504.144511

Fornell, C., and D. F. Larcker. 1981. Evaluating structural equation models with unobservable variables and measurement error. Journal of Marketing Research 18(1):39-50. http://dx.doi. org/10.2307/3151312

Gadsby, S., M. Lockwood, S. Moore, and A. Curtis. 2013. Tasmanian Midlands socio-economic profile. Landscapes and Policy Research Hub, University of Tasmania, Hobart, Australia. [online] URL: http://www.nerplandscapes.edu.au/publication/ tasmanian-midlands-socio-economic-profile-report

Goodwin, C. J. 2010. Research in psychology: methods and design. Sixth edition. John Wiley and Sons, Hoboken, New Jersey, USA.
Graham, J., B. Amos, and T. Plumptre. 2003. Governance principles for protected areas in the 21st Century. Institute on Governance, Ottawa, Ontario, Canada. [online] URL: http:// mercury.ethz.ch/serviceengine/Files/ISN/122197/

ipublicationdocument singledocument/638144bd-f4ba-4324-9c83b63ac434726e/en/pa governance2.pdf

Grothmann, T., and A. Patt. 2005. Adaptive capacity and human cognition: the process of individual adaptation to climate change. Global Environmental Change 15:199-213. http://dx.doi. org/10.1016/j.gloenvcha.2005.01.002

Gunderson, L. H., C. S. Holling, and S. S. Light. 1995. Barriers and bridges to the renewal of ecosystems and institutions. Columbia University Press, New York, New York, USA.

Gupta, J., C. Termeer, J. Klostermann, S. Meijerink, M. van den Brink, P. Jong, S. Nooteboom, and E. Bergsma. 2010. The adaptive capacity wheel: a method to assess the inherent characteristics of institutions to enable the adaptive capacity of society. Environmental Science and Policy 13:459-471. http://dx. doi.org/10.1016/j.envsci.2010.05.006

Hair, Jr., J. F., R. L. Tatham, R. E. Anderson, and W. C. Black. 2006. Multivariate data analysis. Sixth edition. Pearson Prentice Hall, Upper Saddle River, New Jersey, USA.

Holman, I. P., and P. Trawick. 2011. Developing adaptive capacity within groundwater abstraction management systems. Journal of Environmental Management 92:1542-1549. http://dx.doi.org/10.1016/ j.jenvman.2011.01.008

Intergovernmental Panel on Climate Change (IPCC). 2001. Climate change 2001: impacts, adaptation, and vulnerability. A report of Working Group II of the Intergovernmental Panel on Climate Change. Cambridge University Press, Cambridge, UK. [online] URL: http://www.grida.no/publications/other/ipcc tar/? $\underline{\text { src }=/ \text { climate/ipcc tar/wg2/ }}$

Ivey J. L., J. Smithers, R. C. de Loe, and R. D. Kreutzwiser. 2004. Community capacity for adaptation to climate-induced water shortages: linking institutional complexity and local actors. Environmental Management 33:36-47. http://dx.doi.org/10.1007/ $\underline{\mathrm{s} 00267-003-0014-5}$

Kaufmann, D., A. Kraay, and M. Mastruzzi. 2003. Governance matters III: governance indicators for 1996-2002. World Bank, Washington, D.C., USA. [online] URL: http://papers.ssrn.com/ sol3/papers.cfm?abstract id $=405841$

Keohane, R. O. 1986. Reciprocity in international relations. International Organization 40(1):1-27. http://dx.doi.org/10.1017/ $\underline{\text { S0020818300004458 }}$

Kumler, L. M., and M. C. Lemos. 2008. Managing waters of the Pararba do Sul River Basin, Brazil: a case study in institutional change and social learning. Ecology and Society 13(2): 22. URL: http://www.ecologyandsociety.org/vol13/iss2/art22/

Lavrakas, P. J. 2008. Encyclopedia of survey research methods. Sage, Thousand Oaks, California, USA. http://dx.doi. org/10.4135/9781412963947

Lebel, L., J. M. Anderies, B. Campbell, C. Folke, S. HatfieldDodds, T. P. Hughes, and J. Wilson. 2006. Governance and the capacity to manage resilience in regional social-ecological 
systems. Ecology and Society 11(1): 19. URL: http://www. ecologyandsociety.org/vol11/iss1/art19/

Lockwood, M. 2010. Good governance for terrestrial protected areas: a framework, principles and performance outcomes. Journal of Environmental Management 91:754-766. http://dx.doi. org/10.1016/j.jenvman.2009.10.005

Michell, J. 1999. Measurement in psychology: a critical history of a methodological concept. Cambridge University Press, New York, New York, USA. http://dx.doi.org/10.1017/CBO9780511490040

Ministry of Sustainable Resource Management (MSRM). 2004. Governance principles for sustainability: application guidelines. Government of British Columbia, Vancouver, British Columbia, Canada.

Mitchell, M., M. Lockwood, S. A. Moore, and S. Clement. 2014. Incorporating governance influences into social-ecological system models: a case study involving biodiversity conservation. Journal of Environmental Planning and Management http://dx.doi. org/10.1080/09640568.2014.967387

Moon, K., and C. Cocklin. 2011. Participation in biodiversity conservation: motivations and barriers of Australian landholders. Journal of Rural Studies 27:331-342. http://dx.doi.org/10.1016/j. jrurstud.2011.04.001

Mooney, C., D. Defenderfer, and M. Anderson. 2010. Reasons why farmers diversify: Northern Midlands, Tasmania. Rural Industries Research and Development Corporation, Canberra, Australia.

Morrison, M., E. Oczkowski, and J. Greig. 2011. The primacy of human capital and social capital in influencing landholders' participation in programmes designed to improve environmental outcomes. Australian Journal of Agricultural and Resource Economics 55:560-578. http://dx.doi.org/10.1111/j.1467-8489.2011.00554. $\underline{x}$

Morrison, M., and M. Lockwood. 2014. Informing program design for connectivity conservation in the New South Whales Southern Highlands, Australia. Society and Natural Resources 27 (1):70-87. http://dx.doi.org/10.1080/08941920.2013.840814

Moss, S., H. Prosser, H. Costello, N. Simpson, P. Patel, S. Rowe, S. Turner, and C. Hatton. 1998. Reliability and validity of the PAS-ADD Checklist for detecting psychiatric disorders in adults with intellectual disability. Journal of Intellectual Disability Research 42(2):173-183. http://dx.doi.org/10.1046/j.1365-2788.1998.00116. $\underline{\mathrm{X}}$

Nelson, D. R., W. N. Adger, and K. Brown. 2007. Adaptation to environmental change: contributions of a resilience framework. Annual Review of Environment and Resources 32:395-419. http:// dx.doi.org/10.1146/annurev.energy.32.051807.090348

Nelson, R., P. Kokic, S. Crimp, P. Martin, H. Meinke, S. M. Howden, P. de Voil, and U. Nidumolu. 2010b. The vulnerability of Australian rural communities to climate variability and change: part II - integrating impacts with adaptive capacity. Environmental Science and Policy 13:18-27. http://dx.doi. org/10.1016/j.envsci.2009.09.007

Nelson, R., P. Kokic, S. Crimp, H. Meinke, and S. M. Howden. 2010a. The vulnerability of Australian rural communities to climate variability and change: part I - conceptualising and measuring vulnerability. Environmental Science and Policy 13:8-17. http://dx.doi.org/10.1016/j.envsci.2009.09.006

Nelson, R., P. Kokic, L. Elliston, and J.-A. King. 2005. Structural adjustment. A vulnerability index for Australian broadacre agriculture. Australian Commodities 12:171-179.

Nunnally, J. C., and I. H. Bernstein. 1994. Psychometric theory. McGraw Hill, New York, New York, USA.

Ostrom, E. 1990. Governing the commons: the evolution of institutions for collective action. Cambridge University Press, Cambridge, UK. http://dx.doi.org/10.1017/CBO9780511807763

Pahl-Wostl, C. 2009. A conceptual framework for analysing adaptive capacity and multi-level learning processes in resource governance regimes. Global Environmental Change 19:354-365. http://dx.doi.org/10.1016/j.gloenvcha.2009.06.001

Pahl-Wostl, C., M. Craps, A. Dewulf, E. Mostert, D. Tabara, and T. Taillieu. 2007. Social learning and water resource management. Ecology and Society 12(2): 5. [online] URL: http://www. ecologyandsociety.org/vol12/iss2/art5/

Pannell, D. J., G. R. Marshall, N. Barr, A. Curtis, F. Vanclay, and R. Wilkinson. 2006. Understanding and promoting adoption of conservation practices by rural landholders. Australian Journal of Experimental Agriculture 46:1407-1424. http://dx.doi.org/10.1071/ $\underline{\text { EA05037 }}$

Park, S., M. Howden, and S. Crimp. 2012. Informing regional level policy development and actions for increased adaptive capacity in rural livelihoods. Environmental Science and Policy 15:23-37. http://dx.doi.org/10.1016/j.envsci.2011.09.004

Pelling, M., and C. High. 2005. Understanding adaptation: what can social capital offer assessments of adaptive capacity? Global Environmental Change 15:308-319. http://dx.doi.org/10.1016/j. gloenvcha.2005.02.001

Pelling, M., C. High, J. Dearing, and D. Smith. 2008. Shadow spaces for social learning: a relational understanding of adaptive capacity to climate change within organisations. Environment and Planning A 40:867-884. http://dx.doi.org/10.1068/a39148

Peterson, R. A., and Y. Kim. 2013. On the relationship between coefficient alpha and composite reliability. Journal of Applied Psychology 98(1):194-198. http://dx.doi.org/10.1037/a0030767

Plummer, R. 2013. Can adaptive comanagement help to address the challenges of climate change adaptation? Ecology and Society 18(4): 2. http://dx.doi.org/10.5751/ES-05699-180402

Plummer, R., D. R. Armitage, and R. C. de Löe. 2013. Adaptive comanagement and its relationship to environmental governance. Ecology and Society 18(1): 21. http://dx.doi.org/10.5751/ ES-05383-180121

Pretty, J., and H. Ward. 2001. Social capital and the environment. World Development 29(2):209-227. http://dx.doi.org/10.1016/ S0305-750X(00)00098-X

Putnam, R. D., R. Leonardi, and R. Y. Nanetti. 1993. Making democracy work: civic traditions in modern Italy. Princeton University Press, Princeton, New Jersey, USA. 
Raymond, C. M., and J. Cleary. 2013. A tool and process that facilitate community capacity building and social learning for natural resource management. Ecology and Society 18(1): 25. http://dx.doi.org/10.5751/ES-05238-180125

Raymond, C. M., and G. M. Robinson. 2013. Factors affecting rural landholders' adaptation to climate change: insights from formal institutions and communities of practice. Global Environmental Change 23(1):103-114. http://dx.doi.org/10.1016/ j.gloenvcha.2012.11.004

Russell, D. W. 2002. In search of underlying dimensions: the use (and abuse) of factor analysis in Personality and Social Psychology Bulletin. Personality and Social Psychology Bulletin 28:1629-1646. http://dx.doi.org/10.1177/014616702237645

Schneiderbauer, S., L. Pedoth, D. Zhang, and M. Zebisch. 2013. Assessing adaptive capacity within regional climate change vulnerability studies: an Alpine example. Natural Hazards 67:1059-1073. http://dx.doi.org/10.1007/s11069-011-9919-0

Schröter, D., C. Polsky, and A. G. Patt. 2005. Assessing vulnerabilities to the effects of global change: an eight step approach. Mitigation and Adaptation Strategies for Global Change 10:573-595. http://dx.doi.org/10.1007/s11027-005-6135-9

Sexton, J. P., M. W. Schwartz, and B. Winterhalder. 2010. Incorporating sociocultural adaptive capacity in conservation hotspot assessments. Diversity and Distributions 16:439-450. http://dx.doi.org/10.1111/j.1472-4642.2010.00656.x

Sharp, E. A., R. Thwaites, A. Curtis, and J. Millar. 2012. Trust and trustworthiness: conceptual distinctions and their implications for natural resources management. Journal of Environmental Planning and Management 56:1246-1265. http:// dx.doi.org/10.1080/09640568.2012.717052

Smit, B., and J. Wandel. 2006. Adaptation, adaptive capacity and vulnerability. Global Environmental Change 16:282-292. http://dx. doi.org/10.1016/j.gloenvcha.2006.03.008

Smith, B., I. Burton, R. J. T. Klein, and J. Wandel. 2000. An anatomy of adaptation to climate change and variability. Climatic Change 45:223-251. http://dx.doi.org/10.1023/A:1005661622966

Tompkins, E. L., and W. N. Adger. 2005. Defining response capacity to enhance climate change policy. Environmental Science and Policy 8:562-571. http://dx.doi.org/10.1016/j.envsci.2005.06.012

United Nations Development Programme (UNDP). 1997. Governance for sustainable human development: a UNDP policy document. United Nations Development Programme, Rome, Italy. [online] URL: http://www.pogar.org/publications/other/ undp/governance/undppolicydoc97-e.pdf

Vincent, K. 2007. Uncertainty in adaptive capacity and the importance of scale. Global Environmental Change 17:12-24. http://dx.doi.org/10.1016/j.gloenvcha.2006.11.009

Walker, B. H., L. H. Gunderson, A. P. Kinzig, C. Folke, S. R. Carpenter, and L. Schultz. 2006. A handful of heuristics and some propositions for understanding resilience in social-ecological systems. Ecology and Society 11(1): 13. [online] URL: http://www. ecologyandsociety.org/vol11/iss1/art13/
Yohe, G., J. Neumann, P. Marshall, and H. Ameden. 1996. The economic cost of greenhouse-induced sea-level rise for developed property in the United States. Climatic Change 32:387-410. http:// dx.doi.org/10.1007/BF00140353

Yohe, G., and R. S. J. Tol. 2002. Indicators for social and economic coping capacity - moving toward a working definition of adaptive capacity. Global Environmental Change 12:25-40. http://dx.doi. org/10.1016/S0959-3780(01)00026-7 